\title{
Structure of Storyboard for Development of Interactive Learning Objects
}

\author{
Pollyana Notargiacomo Mustaro, Ismar Frango Silveira \\ Nizam Omar, and Sandra Maria Dotto Stump \\ Universidade Presbiteriana Mackenzie - Sao Paulo, SP, Brazil
}

\author{
polly@mackenzie.br ismar@mackenzie.br \\ omar@mackenzie.br sstump@mackenzie.com.br
}

\begin{abstract}
A theoretical discussion and practical guidelines for development and production of learning objects as a result of a structural document named storyboard will be presented. A storyboard must contain instructions and detailed description for development learning objects. During the instructional design phase, the storyboards are elaborated by the instructional designer with collaborate of subject matter expert (SME), graphic artists, programmers, and other interdisciplinary team members research. This involves researches in instructional design procedures and processes for improvement materials, environments and learning experiences and promotes the acquisition of specifics skills and knowledge by students. But one of the problems to create learning objects is the simple transposing of traditional elements for cyberspace without concerning about the instructional strategies or considering learning styles that could be more significant than contentby-strategy. One solution for this problem is using storyboards as model schemes built over some theoretical proposals: Robert Gagné's conditions for learning, levels of interaction present in Rod Sims' Taxonomy, characteristics of hypertext systems presented by Pierre Lévy and George Landow, and orientation in knowledge domain by using diagrams and reduction of information overload, characterized by Richard Wurman.
\end{abstract}

To develop the proposal of storyboards in these molds is necessary to use the ADDIE model with some adaptations. This methodology is used in Instructional System Design (ISD), and it is based on five points: Analysis, Design, Development, Implementation and Evaluation. The analysis phase involves the definition of the learning object, like the content characterize a unit element, the task analysis and description of constraints. The design phase refers to write and measure objectives, to plan instructional strategies, and to development a storyboard with prototype specifications (type of media, presentation strategies, level of interactivity, structure of feedback). The elaboration of storyboards is generally done in development phase, but in this case this suggestion is supported by use of theories cited before to extend the educational possibilities and the motivation of learners. Therefore, the focus of the development phase is to produce learning objects and realize performance, logic and others tests according to the instructions of storyboard. The next step, namely the implementation phase, involves all processes of including learning objects in

Material published as part of these proceedings, either on-line or in print, is copyrighted by Informing Science. Permission to make digital or paper copy of part or all of these works for personal or classroom use is granted without fee provided that the copies are not made or distributed for profit or commercial advantage AND that copies 1) bear this notice in full and 2) give the full citation on the first page. It is permissible to abstract these works so long as credit is given. To copy in all other cases or to republish or to post on a server or to redistribute to lists requires specific permission from the publisher at Publisher@InformingScience.org database with metadata index system. Finally, the evaluation phase measures the whole process (since the conception until the delivery of learning objects), realizing surveys and tests with teachers and students for determining the level of adequacy of learning objects to promote significant learning. 